\title{
The Demise of Technical Subjects: The Case of Selected High Schools in Harare, Zimbabwe
}

\author{
Chakamba John ${ }^{1, *}$, Jumo Cryton ${ }^{1}$, Edziwa Xavier $^{1} \&$ Misozi Chiweshe ${ }^{1}$ \\ ${ }^{1}$ Department of Technical Education, Faculty of Education, University of Zimbabwe, Box \\ MP 167 Mt Pleasant, Harare, Zimbabwe \\ *Corresponding author: E-mail: jchakamba@yahoo.com
}

Received: June 26, $2013 \quad$ Accepted: August 7, 2013 Published: September 18, 2013

doi:10.5296/ije.v5i3.3918 URL: http://dx.doi.org/10.5296/ije.v5i3.3918

\begin{abstract}
This paper reports on some of the factors that draw back effective teaching of technical subjects at high school level. The study was necessitated by the massive donation of textbooks in other subject areas by UNICEF in its Zimbabwe Education Transition Fund. The fund was targeted at reducing student to textbook ratio to $1: 1$ in all subjects. The researchers sought to establish the resource status of secondary schools in the field of Technical Education. Focus was on the availability, relevance, adequacy and state of material resources (books, tools and equipment) and quality of human resources based on qualification and teaching experience. The study included twenty randomly selected high schools in Harare, with Heads of Departments acting as chief respondents. The study was delimited to two subject areas namely; Agriculture and Building Studies. Data was collected using predominantly close-ended questionnaire, with most items weighted on a 5-point Likert scale. Windows SPSS statistics 17.0 was used for data analysis. The main findings, among others included; inadequately qualified teaching personnel, inadequate textbooks, tools and equipment, obsolete tools and equipment and a rather weak support of technical subject departments by school heads. The study calls for the responsible ministry and corporate world to assist in the funding of technical subjects, as these are considered the panacea to a country's unemployment burden.
\end{abstract}

Keywords: technical vocational education; technical subject; resource adequacy; education transition fund; skills acquisition; economic empowerment 


\section{Introduction}

Technical and Vocational Education (TVE) has emerged as one of the most effective human resource development strategies that African countries are embracing in order to train their workforce. TVE is defined as that aspect of education which is a skill acquisition-oriented form of training, based on application of mathematics and scientific knowledge in a specific field for self actualization and development (Puyate, 2008). It can also be defined as an educational process that involves the study of technologies and related sciences and the acquisition of practical skills and knowledge aimed at discovering and developing an individual for employment in various sectors of economic and social life (Boateng, 2012). TVE could, therefore, be taken as a vehicle for rapid industrialization, economic empowerment and social development of the individual. The primary objective of TVE is the acquisition of relevant knowledge, practical skills and attitudes for gainful employment in a particular trade or occupational area after school. The introduction of TVE subjects at high school level, particularly in Africa, is considered a panacea to high youth unemployment rates, if well supported.

\subsection{Background of the Study}

Zimbabwe experienced a decade of economic and political meltdown that saw both the government and parents finding it difficult to run the schools (Coltart, 2010). In 2009 the Ministry of Education (MoE) with assistance from United Nations Children's Fund (UNICEF) embarked on an Education Transition Fund (ETF) that saw both primary and secondary schools availed with textbooks across a wide range of subjects (UNICEF, 2012). The ETF sidelined Technical subjects despite the fact that this sector is generally believed to be a solution to unemployment in the country. It is generally accepted in the education community that it is more costly to offer career and technical education programs than to offer other academic programs. According to Durango, (2002), TVE is naturally expensive by virtue of the equipment required to run the subjects. On the other hand there is a historical negative attitude, from both parents and students, towards the subjects (Mungazi, 1989). According to Mungazi, secondary school education in Zimbabwe was reorganised into F1 and F2 school systems. F1 was meant for a few academically gifted children and F2 was purely a practical biased system for the majority who were declared unsuitable for the F1 system. Following the negative attitude towards technical subjects, perhaps due to historical effects of the F2 education system in Zimbabwe, the possibility of letting the area die naturally is very high. More often technical subjects receive less attention compared to the so-called essential subjects.

Since the beginning of the new millennium, a fresh awareness of the critical role that TVE can play in economic growth and national development has dawned among policy makers in many African countries and within the international donor community. In Zimbabwe, this thrust towards TVE was buttressed by The Presidential Commission of Inquiry into Education and Training led by Dr Nziramasanga in 1999. The commission recommended an outcomes based curriculum, which is broad-based in terms of subjects offered, and which focuses on employment related skills and other essential skills to be developed across the curriculum. This 
expanded concept of career and technical education provides learning experiences that allow students to explore career options, develop academic skills, achieve high academic standards and prepare for industry-defined work or advanced education. Despite the introduction of this expansionist policy in technical education to cover all secondary schools, it is sad to observe that TVE in Zimbabwean high schools is on the decline.

The quality of technical education in schools depends, to a large extent, on the availability of resources (Unterbrunner, 1987). The decade of Zimbabwe's economic meltdown coincided with an increased demand for Technical subjects in neighbouring countries Botswana, South Africa and Namibia which resulted in massive brain drain.

Training for high-quality skills requires appropriate training equipment and tools, adequate supply of training materials, and practice by the learners. Other requirements include relevant textbooks, training manuals and qualified instructors. In general, the quality of training in schools in developing countries is low, with undue emphasis on theory and certification rather than on skills acquisition and proficiency testing. Inadequate instructor training, obsolete training tools and equipment and lack of instructional materials are some of the factors that combine to reduce the effectiveness of training in meeting the required knowledge and skills objectives (Afeti, n.d).

This research was necessitated by the need to establish the resource status in Zimbabwean high schools. The researchers also saw the need to take stock of staff complement of Technical subjects, tools and textbooks in schools. The construct of this paper was to ascertain the resource status and training needs of vocational and technical education in our secondary schools, its consequences in the teaching or imparting of knowledge and coming up with a set of recommendations which would help in solving some of the perennial problems encountered in Zimbabwe high schools.

\subsection{Objectives}

- To establish the qualifications of technical subject teachers in Harare high schools.

- To establish the adequacy of material resources in Harare high schools.

- To determine the relevance of tools and text books in high schools to the demands of the syllabi.

- To determine the attitude of stakeholders towards funding TVE subjects in Harare high schools.

\subsection{Statement of the Problem}

Generally technical education can only yield positive results and an increased uptake where there are high inputs in human and material resources. In its endeavour to reduce the student/ textbook ratio in schools to one child per text book, UNICEF made a generous donation of text books targeting academic subjects only. This could have sent different signals to the corporate world about the status of technical subjects in Zimbabwe. In view of this scenario the researchers sought to investigate the resource status of technical subjects in high schools, 
specifically targeting Agriculture and Building Studies.

\subsection{Justification for the Study}

Technical education is very cardinal to any economic development of the country. Thus this study is important for several reasons. Firstly, researchers concur with the view forwarded by the Nziramasanga Commission (1999) that a new technical education policy should be crafted followed by a massive curriculum transformation biased towards provision of technical subjects from primary school up to tertiary level. This research provides useful information that may aid policy makers in coming up with informed, effective and efficient human resource development policies specifically tailored to suit the envisaged curriculum changes. Political leaders, economic planners and educators in many countries have considered the development of technical and vocational education as the keystone of an educational system best adapted to the individual and the society. The study provides evidence which reinforces the call for a clear and focused policy on technical education in Zimbabwean schools. Such policies will be directed towards making technical education responsive to social and economic development needs of the country through timely provision of human and material resources. The significance of the study also comes from the fact that it sought to examine the current status quo in TVE secondary education system in terms of its human and material resources.

\subsection{Literature Review}

No effective TVE can take place without the adequate provision of learning facilities (Puyate, 2008). Facilities needed in effective implementation of TVE programmes include, among others; textbooks, workshops, tools and equipment.

Textbooks form the basic material for teachers as well as for pupils (Novota, Ridzoňová, Kadnár and Štefková, 2012). A textbook, as the main aid for students, is one of the most important factors which influence the efficiency of learning processes. The researchers appreciate that a written textbook may seem no longer needed in the current information society; however, textbooks cannot be avoided as few schools have access to internet.

It is also generally accepted in the education community that it is more costly to offer technical education programs than to offer other academic programs. The increased costs associated with technical subjects include smaller class sizes, high-cost equipment and consumable instructional materials (Alam, 2008; Mupinga, 2005). During a time of crisis in the United Arab Emirate, Unterbrunner (1987) established that funds for new equipment for use in technical education were only made available sporadically at the end of the fiscal year. The result was that some of the equipment in the workshops was dilapidated and out-dated or obsolete. A funding position for technical subjects in Zimbabwe, post the economic meltdown, is therefore crucial.

The quality of technical education in schools also depends, to a large extent, on the availability of qualified and experienced teachers (Unterbrunner, 1987). At the beginning of the second school term in May 2007, it was reported that up to 2500 teachers, in Zimbabwe, did not report for work in various schools in the country, with Matabeleland provinces and Masvingo being the hardest hit (Mavhunga, Madondo and Phiri, 2009). 


\section{Methodology}

\subsection{Research Design}

A descriptive survey research design was used to determine state of resources in secondary schools in Harare. As Rwodzi, Muchenje and Bondai (2011) put it, surveys allow for the collection of detailed description of existing phenomena with the intent to repeal current practice.

\subsection{Population and Sample}

The population of this study was made up of 47 high schools. All the 47 high schools were offering Agriculture and 22 out of the 47 high schools were offering Building Studies. To ensure proportional representation, two sampling frames were developed based on subjects. Firstly, eight high schools were randomly selected from the 22 schools which were offering BS. Then, in developing a sampling frame for Agriculture, the eight schools selected to participate for BS were excluded leaving 39 schools in the frame. From the 39 schools, 12 were randomly selected to participate for Agriculture. The study targeted Heads of Departments (HODs) only, as these were deemed to be the custodians of departmental information.

\subsection{Instrument}

Data for the study were collected through the use of a questionnaire. The questionnaire had both close-ended and open-ended questions. The researchers developed a three section questionnaire soliciting information on human and material resources, the relevance of tools and text books and financial resources. A 4-point Likert scale (4=all are intact/very relevant; $3=$ most are quite intact/relevant; $2=$ most are torn/somewhat relevant; $1=$ all are torn/not relevant at all) was used to assess the state and relevance of the resources in use at the schools. To measure the adequacy of resources, a 5-point Likert scale (5=very adequate; $4=$ =adequate; $3=$ not sure; $2=$ inadequate; $1=$ not available at all) was used. The instrument was pilot tested for validity and reliability at two secondary schools in a dormitory town of Harare.

\subsection{Data Collection Procedures and Analysis}

Clearance was sought for from the Ministry of Education, Sport and Culture. The researchers administered and collected the questionnaires on the same day. Self administration of questionnaires was meant for researchers to explain the importance and issues.

Data collected were analysed using weighted means and standard deviations derived through SPSS 17.

\section{Presentation and Discussion}

\subsection{Human Resource Qualifications}

Educational backgrounds and teaching experience of respondents had to be established as these had a direct bearing on some questions in the questionnaire. Twenty HODs in Harare secondary schools participated in the study. Of these twenty, 12 were Agriculture and 8 were 
Building Studies. In terms of experience as HODS, 13 (9 Agriculture and 4 Building Studies) had more than 4 years, 5 (3 Agriculture and 2 Building Studies) had 3-4 years while 2 (Building Studies) had 1-2 years. When it concerned educational qualifications, only two high schools had at least one member, in the department, with a degree qualification. While the rest had mostly diploma in education. What was, however, striking were indications that trainee teachers dominated the Building Studies departments.

Qualifications and teaching experience of teachers have been found to be outstanding determinants of the success or failure of any programme. The departments within the schools under study were found to be having few highly qualified teachers. This tends to impact negatively on effective teaching and learning in TVE. The assumption here is that qualified teachers are more effective than their unqualified and inexperienced counterparts.

Uwaifo and Uwaifo (2009) argue that no educational system could rise above the level of quality of its teachers. Thus they argue that technical teachers must be highly trained and acquire enough skills in order to make them capable of communicating their skills to others effectively. What presently obtains is that highly skilled technical subjects' teachers have since migrated to greener pastures or have joined the informal sector thus creating a void in practical subject departments which is difficult to fill.

In some developed countries where technical education has been successful (Japan; America Germany and China), teacher quality in terms of academic qualification and professional qualifications were considered highly in their educational systems. In some countries (Cuba, France and United Kingdom) highly qualified instructors are released from industries to teach in technical schools and full time teachers are required not only to be qualified in their courses but to have spent several years working in industry before taking a teaching career or during training.

\subsection{Perceptions of Respondents Regarding Adequacy of Material Resources}

Respondents were asked to rate the adequacy of a wide range of resources necessary in the teaching and learning of their subjects. Table 1 shows the responses. Mean scores below 2.50 were considered to reflect inadequacy while scores equal to or greater than 2.50 , reflected adequacy.

Table 1: HODs' rating of the adequacy of resources by subjects and levels of education area $(n=20)$

\begin{tabular}{lllllll}
\hline \multicolumn{1}{c}{ Adequacy of } & \multicolumn{3}{c}{ Agriculture } & \multicolumn{3}{c}{ Building Studies } \\
\cline { 2 - 7 } & Mean & SD & Remark & Mean & SD & Remark \\
\hline $\begin{array}{l}\text { Students' text books (junior } \\
\text { secondary) }\end{array}$ & 2.33 & .778 & Inadequate & 2.13 & 1.246 & Inadequate \\
Students' text books (O-level) & 2.42 & .793 & Inadequate & 2.13 & .835 & Inadequate \\
Students' text books (A-Level) & 1.67 & .577 & Inadequate & N/A & & \\
Teachers' resource books & 2.08 & .669 & Inadequate & 3.13 & 1.246 & Adequate \\
Basic tools and equipment & 2.42 & .793 & Inadequate & 2.88 & 1.246 & Adequate \\
Financial resources & 2.42 & .793 & Inadequate & 2.25 & .707 & Inadequate \\
\hline
\end{tabular}


Respondents in both subjects expressed that student text books for all levels and funds for departmental provisions were inadequate. The respondents, however, expressed that basic tools and teacher's text books for Building Studies were adequate. This could possibly be attributed to the general low enrolments in the subject. The average Building Studies class size in Harare is 21 whilst that of Agriculture is 56 (Zimbabwe Schools Examination Council (ZIMSEC), personal communication). From the researchers' experiences, small classes in Building Studies could be attributed to expensive tools used in the subject and migration of trained teachers to other countries to join the construction industry.

\subsubsection{Text book and tool: pupil ratios}

Respondents were further asked to state the textbook to student ratios in their subject areas. The textbook ratio for junior level ranged from 1:1 to 1:10. In Building Studies, 6 respondents cited that their junior textbook ratio was 1:10 while one each cited ratios 1:1 and 1:6. In Agriculture, 8 respondents cited that their junior textbook ratio was 1:10 while the remaining four schools had the ratios 1:1, 1:4, 1:5 and 1:6. Overally it can be confirmed that there was agreement between respondents' rating of adequacy of junior textbooks and the ratios provided.

O-level textbook ratios ranged from 1:1 to 1:22. Thirteen respondents, Agriculture (8) and Building Studies (5) cited 1:10 as their textbook ratio. The same ratio 1:10 was found to be prevalent even in tool ratios. This does not match the assertion by Building Studies respondents that there were adequate basic tools for student use.

Generally, lack of basic tools is a great hindrance to experiential learning, especially with pupils doing Agriculture in urban centres, as this may not accord pupils room to practice and explore. According to Arnold, Warner and Osborne (2006), experiential learning accords the learner room to construct knowledge, skills and values from direct experience.

It should be noted that successful curriculum implementation at any level depends on the availability of basic equipment and other resources like textbooks. Findings seem to indicate that practical subjects are facing serious financial problems simply because the government and existing industries seem not to be coming forward with tangible programmes aimed at resuscitating these subjects which are being threatened by extinction if not addressed. Thus ineffective teaching is reigning supreme and this is contributing to notable poor results. The deteriorating standards in teaching of practical subjects in schools seem to have prompted Zimbabwean authorities to challenge schools to adopt a production system in their curricular aimed at reequipping pupils with practical skills to produce self reliant youths (The Herald, Bulawayo Bureau, 2012). This study revealed that most of the equipment outlined in the syllabus was not available. This seems to defeat the aspect of vocationalisation as the subject matter could be taught in abstract. It has already been mentioned that students following a practically oriented programme should be afforded an opportunity to handle equipment, experiment using various means available and it is through this approach that creativeness is realized and various theories are better explained.

\subsubsection{Condition of material resources}

It is not sufficient to know whether resources are adequate or not without considering their 
condition. Respondents were asked to rate the condition of the textbooks and tools in their respective subject areas. Table 2 shows the responses of the participant HODs. A mean score below 2.50 was taken to signify that most textbooks/basic tools were torn/broken and a score equal to or greater than 2.50 , meant that the textbooks/tools were intact.

Table 2: HODs' rating of condition of listed resources, by subject $(\mathrm{n}=20)$

\begin{tabular}{|c|c|c|c|c|c|c|}
\hline \multirow[t]{2}{*}{ Condition of } & \multicolumn{3}{|c|}{ Agriculture } & \multicolumn{3}{|c|}{ Building Studies } \\
\hline & Mean & SD & Remark & Mean & SD & Remark \\
\hline Students text books (junior) & 2.25 & .622 & $\begin{array}{l}\text { extensively } \\
\text { torn }\end{array}$ & 2.25 & .866 & $\begin{array}{l}\text { extensively } \\
\text { torn }\end{array}$ \\
\hline Students text books (O-level) & 2.33 & .651 & $\begin{array}{l}\text { extensively } \\
\text { torn }\end{array}$ & 1.75 & .707 & $\begin{array}{l}\text { extensively } \\
\text { torn }\end{array}$ \\
\hline $\begin{array}{lll}\text { Students } & \text { text } & \text { books } \\
\text { (A-Level) } & & \end{array}$ & 3.00 & 1.000 & & N/A & & \\
\hline Teachers' resource books & 2.25 & .452 & $\begin{array}{l}\text { extensively } \\
\text { torn }\end{array}$ & 2.00 & .926 & $\begin{array}{l}\text { extensively } \\
\text { torn }\end{array}$ \\
\hline Basic tools for students & 2.25 & .452 & $\begin{array}{l}\text { extensively } \\
\text { broken }\end{array}$ & 2.38 & .518 & $\begin{array}{l}\text { extensively } \\
\text { broken }\end{array}$ \\
\hline
\end{tabular}

The general picture reflected was that material resources for use in the two technical subject areas were in bad state. This confirms the findings by Mashingaidze (1990), who reported that most schools lacked tools and equipment for technical subjects. Mashingaidze also reported that even in schools with the equipment, most of it was found to be badly in need of repair. Zimbabwe's economy started shrinking in the early 2000; therefore, it is most likely that little or no financial resources were devoted to the improvement of resource status of technical subjects, post Mashingaidze report. In a related study by Puyate (2008) in Nigeria, it was established that most of the equipment, tools and workshop facilities that were either broken, damaged or dilapidated, were neither replaced nor renovated. The condition of tools and reference books in schools leaves a lot to be desired. This alone demotivates students who are eager to produce quality artefacts.

Practical subjects are highly capital intensive and require huge sums of money to run. A lot of capital outlay is also required to procure the necessary equipment, machines, tools, facilities and other consumables for effective instruction to take place. Absence of funding was also making it difficult to introduce teachers' in-service programmes. In line with changes in the education system, teachers require in-service support since changes in curriculum usually disorient and deskill many. If enthusiasm about practical subjects is to be strengthened, there must be regular contacts with teachers in the field. Failure to give them guidance and in-service training necessary, practical subjects will continue to be phased out from the school curricular.

\subsubsection{Relevance of resources}

HODs were also asked to rate the relevancy of textbooks in their respective subject areas. Their responses are shown in Table 3. A mean score below 2.50 was taken to signify that the textbooks were not relevant and a score equal to or greater than 2.50 , relevant. 
Table 3: HODs' rating of the relevance of textbooks, by subject area $(n=20)$

\begin{tabular}{lccccccc}
\hline \multirow{2}{*}{ Relevance of } & \multicolumn{3}{c}{ Agriculture } & \multicolumn{3}{c}{ Building Studies } \\
\cline { 2 - 7 } & Mean & SD & Remark & Mean & SD & Remark \\
\hline Students' text books (junior) & 3.00 & .426 & Relevant & 2.75 & .866 & Relevant \\
Students' text books (O-level) & 3.00 & .426 & Relevant & 2.75 & .866 & Relevant \\
Students' text books (ALevel) & 3.50 & .707 & Relevant & N/A & & \\
Teachers' text books & 2.92 & .515 & Relevant & 2.75 & .866 & Relevant \\
\hline
\end{tabular}

There was consensus across the two subject areas that textbooks for pupils and teachers' were relevant. This was a positive outcome which may imply that the demand of syllabi were met through the use of relevant textbooks. However, the concern was on the books that were torn and not easy to use (Table 2).

3.3 Perceptions of Respondents Regarding Attitudes of Stakeholders towards Funding of TVE Subjects

The success and enhancement of technical subjects at a school depends largely on how administration, parents and financiers view the subjects. Technical subjects in Zimbabwe are generally viewed negatively because of historical reasons (Mandebvu 1989). The researchers enquired from the HODs, on the attitude of the school development committees (SDCs), school heads and parents towards technical subjects. There were varied terminologies used to express the attitudes.

The responses showed that SDCs were fairly supportive although at times they set their priorities wrong. The general picture portrayed on school heads' attitudes was that a majority were not supportive of technical subjects and teachers had to expend energy in persuading them to address the needs of the subjects. Terms used to describe the attitudes included; "... not predictable; ... takes a lot of persuasion to get a hearing; ... prefer academic subjects; ... head stumbling block; and takes my subject last on priorities". This is not peculiar to Zimbabwe because the same has been recorded time immemorial. However, in countries like Kenya and Ghana, support for technical subjects is a priority issue (Okaka, 1998).

Parents were said to be generally supportive of the subjects, however, they had difficulties in registering their children for examinations in the subjects, especially Building Studies. According to the respondents, ZIMSEC charges a practical fee which is an extra cost to the parents. The parents end up foregoing registering the subject.

Uwaifo and Uwaifo (2009) in a similar study conducted in Nigeria observed the existence of two schools of thought militating against proper teaching of practical subjects in schools. The first being the general belief that it is expensive to establish and maintain practical subjects in any given curricular. Another similar school of thought believe that the major impediment is that of a negative attitude of the society towards skilled programmes, with the society preferring intellectually oriented programmes to skilled ones hence absence of interest for 
occupational programmes.

Thus the attitude of heads of schools, communities and the policies of the examination body (ZIMSEC) on matters concerning practical subjects should be revisited if improvement is expected in this area. In addition the government has not been fair enough with its funding policy. For example UNICEF came up with a noble programme aimed at reducing student/textbook ratio in schools. Not even a single practical subject was catered for in this programme. This negative perception of practical subjects was cascaded down to the pupil and communities. The negative attitude towards practical subjects should be addressed through reorientation programmes aimed at enlightening parents on the need for their children to be practically oriented in light of the prevailing economic challenges the country is going through.

\section{Conclusion and Recommendations}

Despite Zimbabwe's thrust towards TVE, the situation on the ground is to the contrary. From the results of this study it can be concluded that the demise of technical subjects in Zimbabwe may be attributed to a host of problems the major one being the dearth of qualified teachers to effectively teach practical subjects, poor funding by the government, industry, parents and the donor community. The situation was compounded by the economic meltdown and the massive brain drain to neighbouring countries in the last decade. The implication of the foregoing is that schools are failing to meet the basic requirements of the syllabi hence students are not receiving the envisaged basic skills. This impedes on the training of students leading to the churning out of graduates with inadequate job skills. The future of technical subjects remains bleak as they are still sidelined. It appears the subjects are not a priority.

In light of these findings it is recommended that the government and the corporate world step up efforts fund technical vocational curricula in schools. Funding of practical subjects will inturn stimulate students' interest in the subjects. The corporate world can adopt specific schools for re-tooling and equipping while the government ensures that teachers are trained and remunerated well to curb brain drain. There may be need for schools to embark on income generating projects that can contribute the sustenance of the technical subject departments.

\section{References}

Afeti, G. (nd). Technical and Vocational Education and Training for Industrialization. $\begin{array}{llll}\text { Retrieved October } & \text { 8, } & \text { from }\end{array}$ www.arrforum.org/index.php?option=com_content\&view $=$ article\&id=95\%3Atechnicaland-vocational-education-and-training-for-industrialization $\&$ catid $=40 \&$ Itemid $=41$

Alam, G.M. (2008). The role of technical and vocational education in the national development of Bangladesh. Retrieved October 12, 2011 from www.apjce.org/files/APJCE_09_1_25_44.pdf

Arnold, S., Warner, W.J., \& Osborne, E.W. (2006). Experiential learning in secondary 
agricultural education classrooms. Journal of Southern Agricultural Education Research, 56(1), 30-39.

Boateng, C. (2012). Restructuring Vocational and Technical Education in Ghana: The Role of Leadership Development. International Journal of Humanities and Social Sciences, 2(4), 108-114.

Coltart, D. (2010). Education Transition Fund Sensitisation. Retrieved January 23, 2012 from www.davidcoltart.com/2010/08/education-transition-fund-sensitisation

Durango, L. (2002). The Financing of Technical and Vocational Education (TVET): Options and challenges for Sub-Saharan Africa. Paper presented to Nordic UNEVOC Network on training for survival and development in Southern Africa. Skills development and entrepreneurship education in international development co-operation- experiences and prospects. Oslo, Norway.

Mandebvu, O.S. (1989). Pupils’ Attitudes towards technical subjects: An exploratory study. Unpublished M.A Thesis, Linkoping University.

Mavhunga, P.J., Madondo, M., \& Phiri, M. (2009). Education for all in Zimbabwe: A mirage? Zimbabwe Journal of Educational Research, 21(1), 25-47. http://dx.doi.org/10.4314/zjer.v21i1.44066

Mungazi, D.A. (1991). Colonial education for Africans: George Stark's policy in Zimbabwe. New York: Praeger Publishers.

Mupinga, D.M., Burnett, M.F., \& Redmann, D.H. (2005). Examining the purpose of technical education in Zimbabwe's high schools. International Education Journal, 6(1), 75-83.

Novota, M., Ridzoňová, Z., Kadnár, J., \& Štefková, P. (2012). Secondary schools graduates’ attitudes towards textbooks for vocational education. International Journal of Vocational and Technical Education, 4(2), 25-28.

Nziramasanga, C.T. (1999). Zimbabwe report of the Presidential Commission of Inquiry into Education and Training. Harare: Government Printers.

Okaka, P.O. (1998). Technical and vocational education and training policy in Kenya. Retrieved September 10, 2011 from www.voced.edu.au/content/ngv10372

Puyate, S.T. (2008). Constraints to the effective implementation of vocational education program in private secondary schools in Port Harcourt local government area. Asia-Pacific Journal of Cooperative Education, 9(1), 59-71.

Rwodzi, M., Muchenje, F., \& Bondai, B. (2011). Student teacher perceptions of the role of classroom mentors on attachment teaching practice: The case at Morgan ZINTEC college. Zimbabwe Journal of Educational Research, 23(3), 236-258.

UNICEF (2012). Education Transition Fund Distribution launch. Retrieved May 13, 2012 from http://www.unicef.org/zimbabwe/media_6408.html 
Unterbrunner, H. (1987). Technical and Vocational Education and Training. Retrieved November 10, 2011 from www.unesdoc.unesco.org/images/0007/000772/077281 eo.pdf

Uwaifo, V.O., \& Uwaifo, I.U. (2009). Training technology and vocational education teachers for the new 9-3-4 education system in Nigeria: Its problems and prospects. International NGO Journal, 4(4), 160-166.

\section{Copyright Disclaimer}

Copyright reserved by the author(s).

This article is an open-access article distributed under the terms and conditions of the Creative Commons Attribution license (http://creativecommons.org/licenses/by/3.0/). 